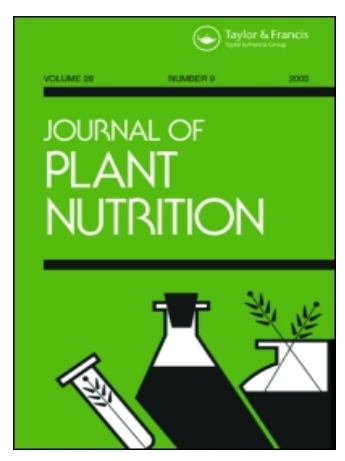

Journal of Plant Nutrition

ISSN: 0190-4167 (Print) 1532-4087 (Online) Journal homepage: https://www.tandfonline.com/loi/lpla20

\title{
Nitrogen doses on physiological attributes and yield of sugarcane grown under subsurface drip fertigation
}

\section{Andressa Freitas de Lima Rhein \& Marcelo de Almeida Silva}

To cite this article: Andressa Freitas de Lima Rhein \& Marcelo de Almeida Silva (2017) Nitrogen doses on physiological attributes and yield of sugarcane grown under subsurface drip fertigation, Journal of Plant Nutrition, 40:2, 227-238, DOI: 10.1080/01904167.2016.1237646

To link to this article: https://doi.org/10.1080/01904167.2016.1237646

Accepted author version posted online: 11

Oct 2016

Published online: 07 Dec 2016.

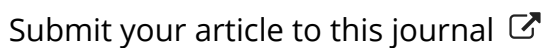

Џ Article views: 178

View Crossmark data $\complement$

Citing articles: 2 View citing articles $匚$ 


\title{
Nitrogen doses on physiological attributes and yield of sugarcane grown under subsurface drip fertigation
}

\author{
Andressa Freitas de Lima Rhein ${ }^{\mathrm{a}}$ and Marcelo de Almeida Silva ${ }^{\mathrm{b}}$ \\ aSecretaria do Verde e do Meio Ambiente, Prefeitura do Município de São Paulo, São Paulo, Brazil; 'baboratório de \\ Ecofisiologia Aplicada à Agricultura, Departamento de Produção e Melhoramento Vegetal, Faculdade de Ciências \\ Agronômicas, Universidade Estadual Paulista (UNESP), Botucatu, Brazil
}

\begin{abstract}
Soil hydric availability and nitrogen fertilization are important environmental factors that influence sugarcane production. In the present study, the physiological attributes SPAD index, maximum photochemical efficiency of photosystem II $\left(\mathrm{F}_{\mathrm{v}} / \mathrm{F}_{\mathrm{m}}\right)$, leaf area index $(\mathrm{LAl})$, chlorophyll and carotenoid content, and sugarcane productivity were assessed under different nitrogen doses $(0,50$, 100,150 , and $200 \mathrm{~kg} \mathrm{~N} \mathrm{ha}^{-1}$ ) applied in the form of urea via subsurface drip fertigation. The physiological attributes were determined 38, 121, 208, 291, and 381 days after the third harvest (DAH), and stalk and sugar productivity at 381 $\mathrm{DAH}$. The $100 \mathrm{~kg} \mathrm{~N} \mathrm{ha}^{-1}$ dose has produced better results for the sugarcane physiological attributes. Increasing doses of nitrogen applied via subsurface drip fertigation increased the productivity of stalks and sugar considerably.
\end{abstract}

\section{ARTICLE HISTORY}

Received 3 April 2014

Accepted 3 June 2016

\section{KEYWORDS}

Saccharum spp.; full irrigation; nitrogen fertilization; chlorophyll; productivity

\section{Introduction}

Sugarcane, Saccharum spp., is distinctively one of the best sources of renewable energy, making the case for it to be an important crop in Brazil and in the world. Remarkably, it presents a wide adaption scale, being cultivated in tropical and subtropical regions, including more than 90 countries between parallels $35^{\circ} \mathrm{N}$ and $30^{\circ} \mathrm{S}$ (Alfonsi et al., 1987). Sugarcane is cultivated in different soil types, under the influence of several abiotic factors in each region, showing different levels of production (Silva et al., 2008). Among the environmental factors that reduce the plant growth and development, water deficiency is considered one of the most important limitations to productivity and distribution of crops, having a negative influence on $10 \%$ of the agricultural areas in the globe (Bartels and Sunkar, 2005), particularly in crops of great economic importance, such as rice, corn, wheat, and sugarcane. Such limitations are due to the fact that water deficiency causes severe damages to plant growth, mainly through the reduction of cellular expansion (Taiz and Zeiger, 2010). Taking this aspect into account, sugarcane producers are heavily dependent on irrigation in order to reach production targets (Silva et al., 2007). Besides leading to an increase in productivity, reaching amounts larger than 100\%, irrigation also allows for a longer time of plant exploration as well as a larger number of harvests (Dalri et al., 2008). However, water for irrigation is a limited and contentious resource, which means an effective management is essential, not only to reduce prodigal use, but also to reduce production costs, and maintain productivity (Silva et al., 2007).

Nitrogen fertilization is also one of the main abiotic factors that determine the sugarcane production, particularly regarding the longevity of ratoons (Muchow et al., 1996; Vale et al., 2013). Nitrogen is the fertilizer that is most frequently applied through water irrigation, given that, compared to other nutrients such as phosphorus, potassium, calcium, and magnesium, it presents high mobility in the soil, although it has a high loss potential,

CONTACT Marcelo de Almeida Silva marcelosilva@fca.unesp.br $@$ Departamento de Produção e Melhoramento Vegetal, Faculdade de Ciências Agronômicas (UNESP), Rua José Barbosa de Barros, 1780, Botucatu, SP CEP 18610-307, Brazil.

(c) 2017 Taylor \& Francis Group, LLC 
mainly due to nitrate leaching (Roberts, 2008). Fertigation allows for wider nutrient lateral and vertical movements, which is considerably important in perennial and semi-perennial crops (Phogat et al., 2013), given the difficulty to incorporate side-dressing without damaging the root system (Vieira et al., 2010).

Although it constitutes exclusively $1 \%$ of the total sugarcane dry matter, nitrogen is directly involved in the synthesis of amino acids, in the composition of the chlorophyll molecule, and the production of carbohydrates, and, therefore, plays a determinant role in crop development (Vitti et al., 2010). Studies reveal that chlorophyll concentration or greening of leaves is positively correlated to the leaf nitrogen concentration, given that most of the $\mathrm{N}$ contained in leaves is in the chloroplasts, participating in the synthesis and structure of chlorophyll molecules (Torres Netto et al., 2005). Moreover, the function of such element in the metabolism of carbohydrates and in forming the chlorophyll molecule contributes positively to the growth and quality of stalks in the milling process, as well as to the vigor of the plant (Shekinah et al., 2012). Nevertheless, nitrogen fertilization is distinctively one of the management practices with the highest research demand for sugarcane, because studies on nitrogen present very varied and even contradictory results, as well as the response mechanisms have not been completely elucidated (Vale et al., 2013).

For the reasons explained above, the objective of the present research was to characterize sugarcane physiological attributes and productivity under nitrogen doses applied via subsurface drip fertigation.

\section{Materials and methods}

The experimental area was installed in November 2006, in a location close to the town of Jaú, São Paulo state, Brazil $\left(22^{\circ} 17^{\prime} \mathrm{S}\right.$ and $48^{\circ} 34^{\prime} \mathrm{W}, 580 \mathrm{~m}$ of altitude). The climate in the region is Aw (Köppen), tropical rainy with dry winter, annual averages of $22.7^{\circ} \mathrm{C}$ for temperature and $1,344 \mathrm{~mm}$ for precipitation. Soil has been classified as Eutrophic Argisoil. Before the experiment was installed, soil samples were collected from layers at $0-20,20-40$, and $40-80 \mathrm{~cm}$ for chemical and granulometric analysis (Table 1).

The experimental plots were made of five double furrow lines $(0.40 \times 1.40 \mathrm{~m})$ with $8 \mathrm{~m}$ in length. Between the double furrows, dripping tubes of the irrigation system $(22135 \mathrm{FL}$, DripNet PC, Adana, Turkey) were buried at $20 \mathrm{~cm}$ of depth, with drippers every $0.5 \mathrm{~cm}$ and flow rate of $1.0 \mathrm{~L} \mathrm{~h}^{-1}$.

The present study was carried out between September 2009 and October 2010, after the third cut of sugarcane SP80-3280. The soil hydric condition was monitored by tensiometers and the frequency of irrigation was calculated based on the available water capacity (AWC) in the soil of $70 \mathrm{~mm}$, precipitation (P), atmospheric demand, and sugarcane evapotranspiration (ETC). Total rainfall during the experiment period was $1,435 \mathrm{~mm}$. The amount of water applied by the irrigation system was $390 \mathrm{~mm}$, distributed throughout the sugarcane development cycle, in order to supply $100 \%$ of the crop's

Table 1. Chemical and particle size analysis of soil Eutrophic Argisoil the experimental area.

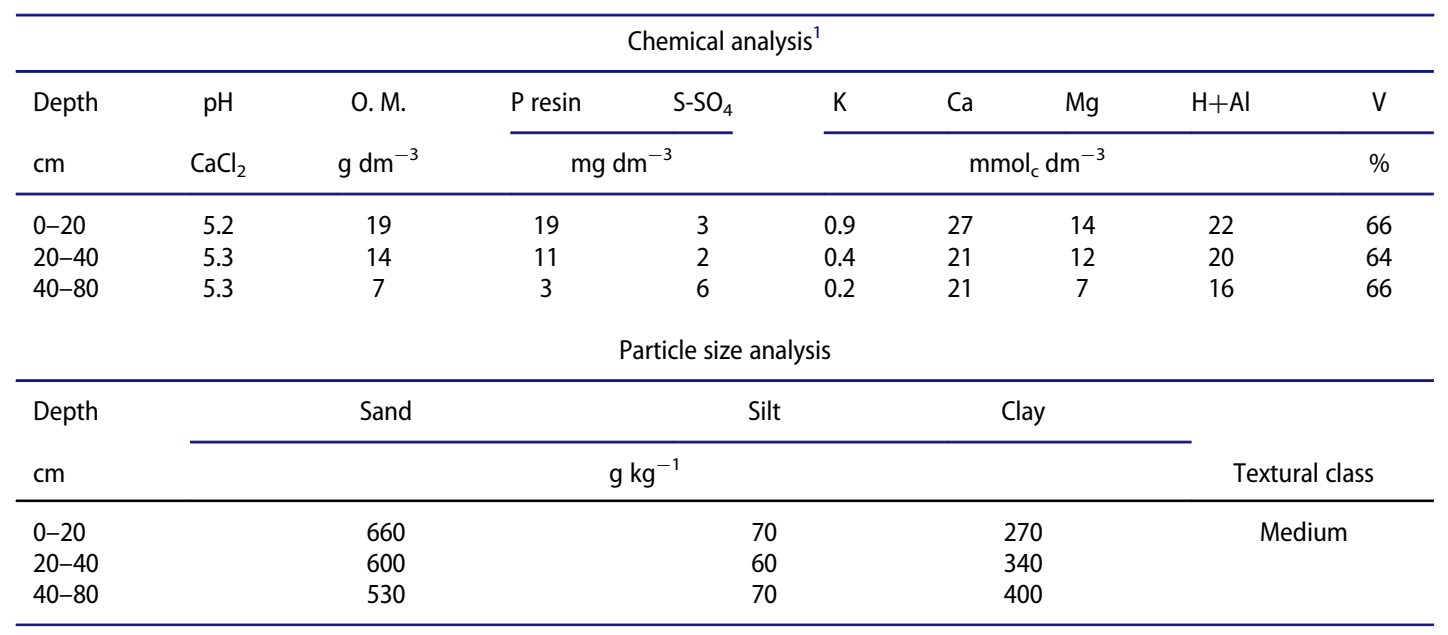

1O.M.: organic matter; V: base saturation. 


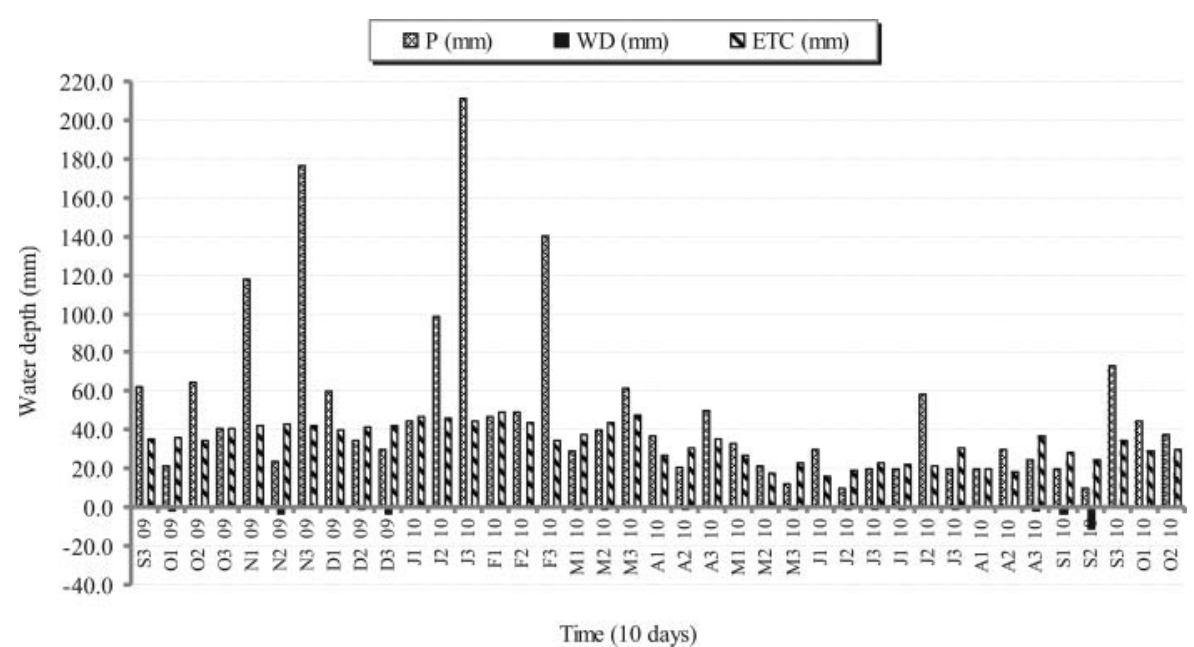

Figure 1. Decendial water balance in subsurface drip irrigation management from September 2009 to October 2010. $P=$ precipitation + water depth; WD = water deficit; ETC = crop evapotranspiration.

evapotranspiration, in accordance with the Penman-Monteith method (Howell and Evett, 2004), which had an accumulation of $1,320 \mathrm{~mm}$ (accumulated ETC). Thereby, the ten-day water balance was estimated and water deficit (WD) was calculated, reaching only $28 \mathrm{~mm}$ (Figure 1).

Different nitrogen doses $\left(0,50,100,150\right.$, and $\left.200 \mathrm{~kg} \mathrm{~N} \mathrm{ha}^{-1}\right)$, in the form of urea $(45 \% \mathrm{~N})$, were applied via full subsurface fertigation twice a week, distributed between the harvest of the previous cycle up to four months before the next harvest. $150 \mathrm{~kg} \mathrm{ha}^{-1}$ dipotassium oxide $\left(\mathrm{K}_{2} \mathrm{O}\right)$ in the form of potassium chloride $(\mathrm{KCl})$ was also added to the treatments and distributed throughout the cycle, with such application being interrupted three months prior to the harvest. Physiological attributes were determined in five periods of plant development: 38, 121, 208, 291, and 381 days after third cut (DAC), in a central meter of the double furrow of each plot. The chlorophyll content estimation (SPAD index) was determined by a chlorophyll meter (SPAD-502, Minolta Corp., Ramsey, NJ, USA). Contents of chlorophyll $a, b$, total $(a+b)$, chlorophyll ratio $a / b$ and carotenoids were determined in ten discs removed from leaves +1 (Top Visible Dewlap) from each plot and immersed in dimethylformamide for 24 hours, and the extract was read in spectrophotometer in different wave lengths according to Lichtenthaler (1987). The maximum photochemical efficiency of photosystem II $\left(F_{V} / F_{M}\right)$ was obtained using a portable fluorometer (OS-30p, Opti-Sciences, Inc., Hudson, NH, USA). The leaf area index (LAI) was determined between 1 and 2 pm using a ceptometer (Accupar LP-80, Decagon Devices, Inc., Pullman, WA, USA).

The stalks productivity (TSH), $\mathrm{t}$ stalk ha ${ }^{-1}$, was determined by the weight of stalks in each plot at $381 \mathrm{DAC}$. The sugar productivity (TPH), $\mathrm{t}$ pol ha ${ }^{-1}$, was obtained by the product between TSH and the apparent sugar percentage in the stalks (PCC). Thereby, the experimental design used for the physiological attributes was randomized blocks, in a $5 \times 5$ factorial scheme, with the following factors: nitrogen doses $(\mathrm{N})$ and evaluation period (E), in four repetitions. For TSH and TPH, randomized blocks experimental design was also used, according to nitrogen doses, in four repetitions. Data was submitted for variance analysis by test $\mathrm{F}$ followed by the application of Turkey test (5\%) for comparing the averages. The analysis of polynomial regression was used to decompose the degrees of freedom of the quantitative factor nitrogen doses applied via subsurface drip fertigation.

\section{Results and discussion}

\section{Physiological attributes}

The SPAD index decreased significantly throughout the evaluation seasons, independently of the 0,50 , 100,150 , and $200 \mathrm{~kg} \mathrm{~N} \mathrm{ha}^{-1}$ doses applied via subsurface drip fertigation (Figures 2A, 2B, 2C, 2D, and 
(A)

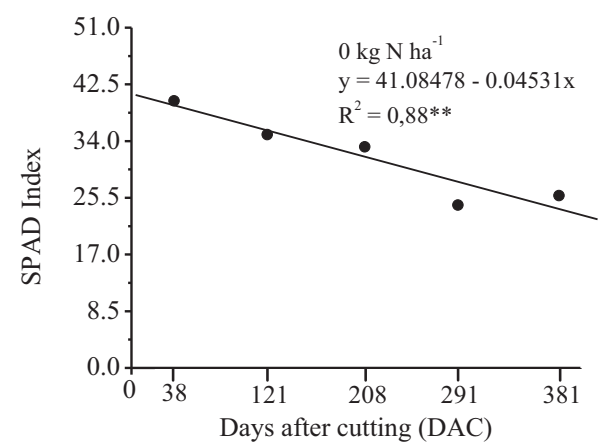

(C)

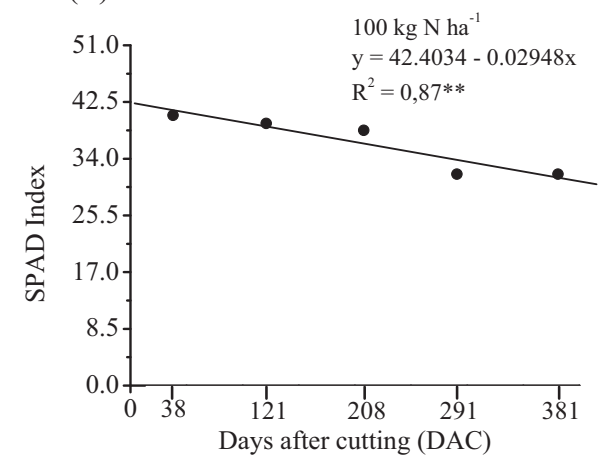

(B)

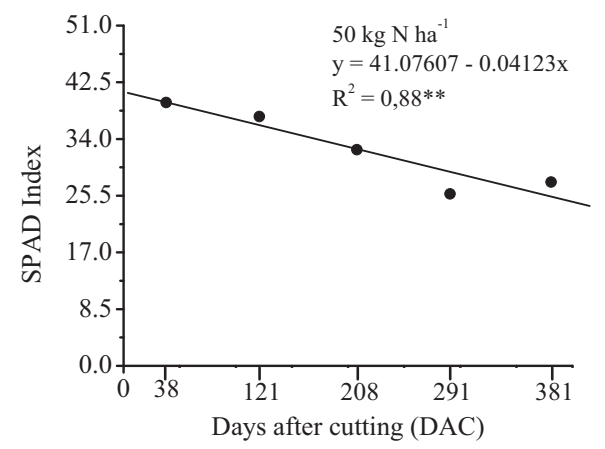

(D)

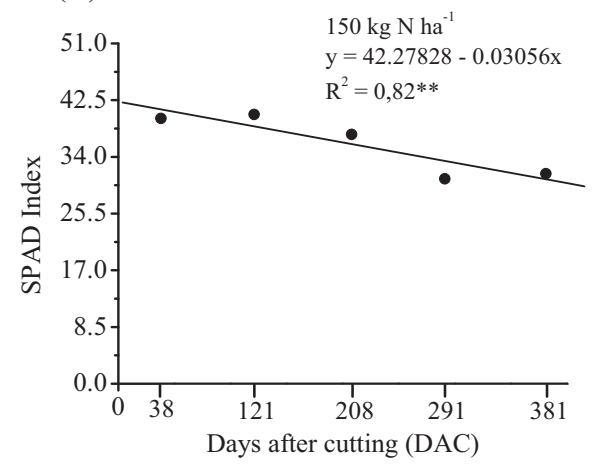

(E)

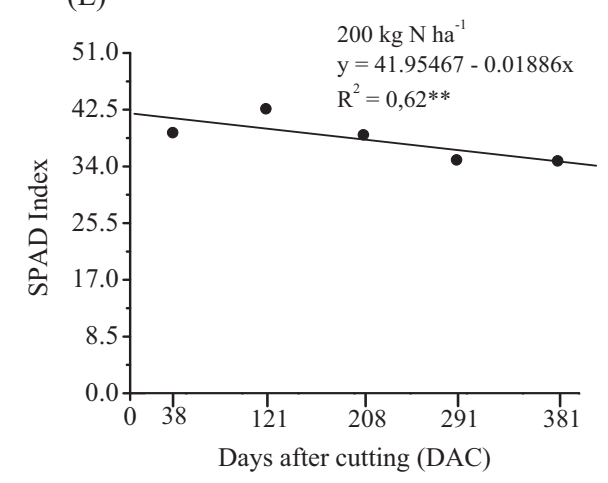

Figure 2. Mean values of SPAD index for sugarcane cv. SP80-3280, using five evaluation periods $(38,121,208,291$, and 381 DAC) in doses of $0,50,100,150$, and $200 \mathrm{~kg} \mathrm{~N} \mathrm{ha}^{-1}$ applied via subsurface drip fertigation represented in graphs $A, B, C, D$, and $E$, respectively. Jaú, SP, Brazil. 2009-2010.

2E, respectively). Such decrease, particularly from 208 days after cut onwards, is due to the vigorous vegetative growth of the crop induced by the $\mathrm{N}$-fertilizer, causing the dry matter production rate to exceed the nitrogen accumulation rate in plant issues (Vitti et al., 2010), since the plant develops in other organs, such as roots and stalks, which act as drains and reduce nitrogen concentration in the leaves (Oliveira et al., 2005).

On the other hand, the SPAD index has increased significantly according to the increase in nitrogen doses applied via subsurface drip fertigation 121, 208, 291, and 381 DAC (Figures 3A, 3B, 3C, and 3D, respectively). In the first evaluation, $38 \mathrm{DAC}$, no difference was verified in the reading of the SPAD index, which may have occurred due to the reduced time for the absorption of nitrogen applied via subsurface dripping. Moreover, at the beginning of its development, sugarcane presents a reduced demand for this nutrient, given its slow initial growth (Vitti et al., 2010). 
(A)

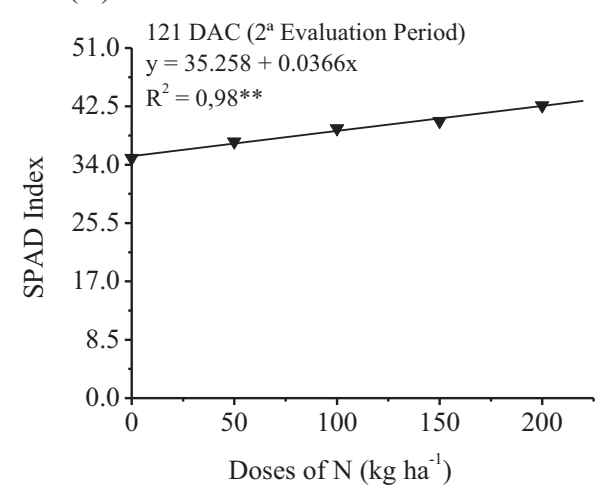

(C)

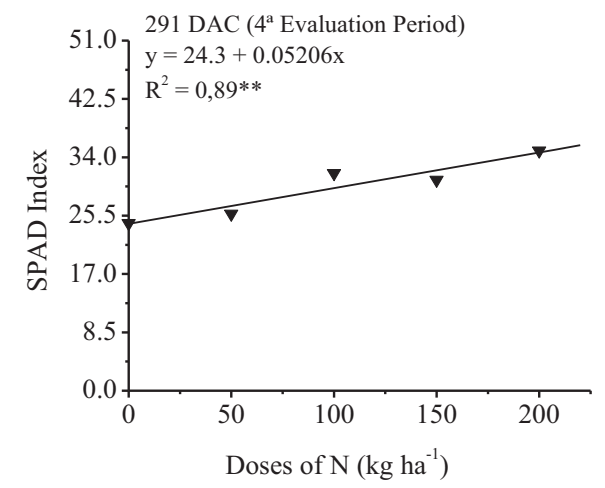

(B)

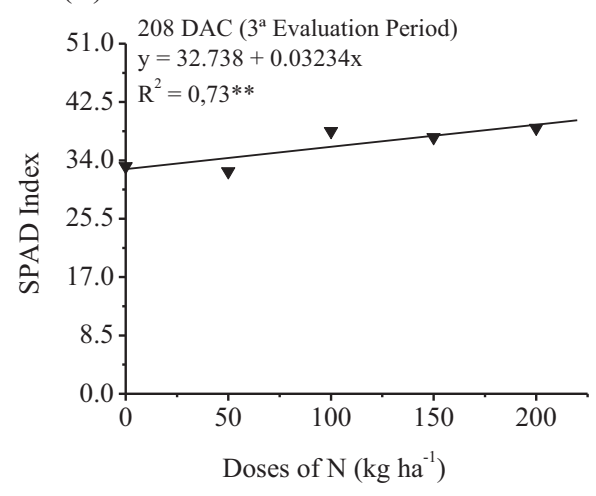

(D)

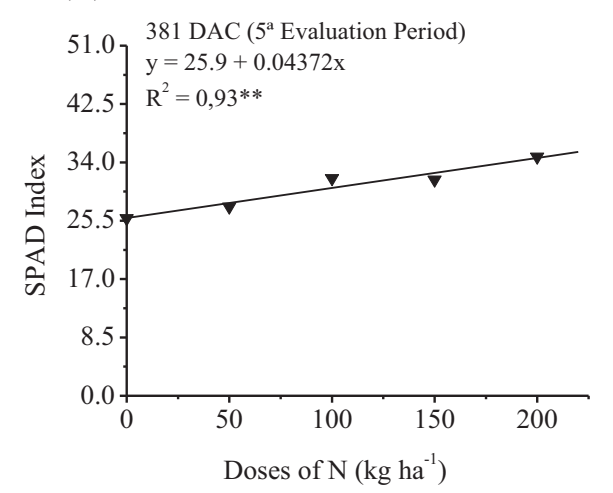

Figure 3. Mean values of SPAD index for sugarcane cv. SP80-3280, obtained under doses of nitrogen $(0,50,100$, 150, and $200 \mathrm{~kg} \mathrm{~N} \mathrm{ha}^{-1}$ ) applied via subsurface drip fertigation in four evaluation periods (121, 208, 291, and 381 DAC), represented in graphs A, B, C, and D, respectively. Jaú, SP, Brazil. 2009-2010.

Other studies have revealed that sugarcane plants cultivated under different nitrogen concentrations have presented a considerable increase in SPAD index values (Kawamitsu et al., 1999). Glaz et al. (2008) have verified the significant increase in SPAD index in sugarcane under flood periods associated to nitrogen fertilization with 84 and $113 \mathrm{~kg} \mathrm{~N} \mathrm{ha}^{-1}$.

The chlorophyll $a, b$, total $(a+b)$, and carotenoids contents increased due to the nitrogen doses, reaching the highest value under the application of $200 \mathrm{~kg} \mathrm{~N} \mathrm{ha}^{-1}$ via subsurface dripping, however, the chlorophyll ratio $a / b$ did not demonstrate change according to such doses (Table 2). The increments verified due to the increase in nitrogen doses under full irrigation was evidence by the fact that such nutrient is part of the constitution of chlorophyll molecules, which captures luminous energy through photosystems I e II of the photochemical phase of photosynthesis, used for the conversion into the chemical energy necessary to incorporate and form carbonated skeletons (Pedó et al., 2012).

Studies have reported that the accumulation of carotenoid pigments in plants may be influenced by physiological and biochemical attributes, as well as abiotic factors, such as light, temperature, and fertility, particularly nitrogen fertilization (Kopsell et al., 2007). Studies with basil (Politycka and Golcz, 2004) and spinach (Lefsrud et al., 2007) have recorded an increase in carotenoid pigments contents proportional to higher nitrogen concentration.

Results have also shown that chlorophyll $a, b$, total $(a+b)$, and carotenoids contents decreased throughout the evaluation periods, particularly from 208 DAC onwards (Table 3), such as observed for the SPAD index (Figure 2). The highest concentration of photosynthetic pigments observed until this period with reduction afterwards matches with the period of more vigorous crop development, characterized by intense tillering and leaf expansion, and from this period on, such pigment start to decrease 
Table 2. Tukey test for contents of chlorophyll $a(C C a), b(C C b)$, Total $(C C(a+b))$, ratio chlorophyll $a / b(C C(a / b))$, and the carotenoid pigments contents (CAROT) for sugarcane Cv. SP80-3280, obtained for doses of nitrogen (0,50, 100, 150, and $200 \mathrm{~kg} \mathrm{ha}^{-1}$ ) applied via subsurface drip fertigation. Jaú, SP, Brazil, 2009-2010.

\begin{tabular}{lllllc}
\hline & $\mathrm{CC} a$ & $\mathrm{CC} b$ & $\mathrm{CC}(a+b)$ & $\mathrm{CC}(a / b)$ & CAROT \\
\cline { 2 - 5 } Doses of $\mathrm{N}\left(\mathrm{kg} \mathrm{ha}^{-1}\right)$ & & & $\left(\mu \mathrm{g} \mathrm{cm}^{-2}\right)$ & & \\
\hline 0 & $17.75 \mathrm{c}^{2}$ & $5.00 \mathrm{c}$ & $22.75 \mathrm{c}$ & 3.77 & $1029.14 \mathrm{c}$ \\
50 & $22.50 \mathrm{~b}$ & $6.38 \mathrm{~b}$ & $28.88 \mathrm{~b}$ & 3.71 & $1261.11 \mathrm{ab}$ \\
100 & $22.94 \mathrm{ab}$ & $6.65 \mathrm{ab}$ & $29.59 \mathrm{ab}$ & 3.71 & $1388.40 \mathrm{ab}$ \\
150 & $25.13 \mathrm{ab}$ & $7.12 \mathrm{ab}$ & $32.25 \mathrm{ab}$ & 3.61 & $1257.13 \mathrm{~b}$ \\
200 & $26.79 \mathrm{a}$ & $7.67 \mathrm{a}$ & $34.47 \mathrm{a}$ & 3.61 & $1449.32 \mathrm{a}$ \\
LSD $^{1}$ & 4.02 & 1.27 & 5.25 & $\mathrm{NS}^{3}$ & 189,43 \\
\hline
\end{tabular}

${ }^{1}$ LSD represents least significant difference.

${ }^{2}$ Means within a column followed by the same letter are not significant at $P \leq 0.05$.

${ }^{3} \mathrm{NS}$ represents not significant at $P \leq 0.05$.

with leaf senescence, process through which leaves slowly loose such pigments, RNA, lipids, and proteins, even under humidity maintenance and nutrients provision (Taiz and Zeiger, 2010). The similarity in the response between photosynthetic pigments and the SPAD index is explained by the positive and significant correlation between both variables (Silveira et al., 2003).

Two of the main pigments related to photosynthetic efficiency and, as a consequence, to plant growth and adaptation to different environment are chlorophyll $a$ and carotenoids (Force, 2003). Due to their unstable chemical structure, chlorophylls are easily degraded, leading to decomposition product that modifies the perception and quality of plants. There is also variation in the carotenoid content according to different cultivars, stages of maturation, climate conditions, or geographical location, as well as to the part of the plant that was used and the agricultural production technique (Meschede et al., 2011).

Moreover, the chlorophyll ratio $a / b$ has recorded a significant increase throughout the experimental evaluations (Table 3). Such behavior is evidenced by the greater degradation of chlorophyll $b$ compared to chlorophyll $a$. As a matter of fact, in the leaf senescence stage, the first step of degradation of chlorophyll $b$ involves its conversion into chlorophyll $a$ (Santos et al., 2001).

The maximum photochemical efficiency of photosystem II $\left(F_{V} / F_{M}\right)$ has also increased with the increment of nitrogen doses, particularly under the application of 100 and $150 \mathrm{~kg} \mathrm{~N} \mathrm{ha}^{-1}$ via subsurface dripping. Nevertheless, it decreased depending on the evaluation periods, particularly 291 days after cut and beyond (Table 4 ).

Photosynthesis occupies a central position in metabolism and provides the connection between the plant's internal processes and the external environment. The use of chlorophyll fluorescence parameters has been widespread, particularly in studies on the photosynthetic capacity of plants, because it is a non-destructive method that allows the qualitative and quantitative analysis of the absorption and

Table 3. Tukey test for contents of chlorophyll $a(\mathrm{CCa}), b(\mathrm{CC} b)$, Total [CC $(a+b))$, ratio chlorophyll $a / b(C C(a / b)]$, and carotenoids pigments contents (CAROT) for sugarcane cv. SP80-3280, obtained in five evaluation periods (38, 121, 208, 291, and 381 DAC) applied via subsurface drip fertigation. Jaú, SP, Brazil, 2009-2010.

\begin{tabular}{lccccc}
\hline & $C C a$ & $C C b$ & $C C(a+b)$ & $C C(a / b)$ & CAROT \\
\cline { 2 - 5 } Evaluation period & & & $\left(\mu \mathrm{g} \mathrm{cm}^{-2}\right)$ & & \\
\hline 1st (038 DAC) & $30.26 \mathrm{a}^{2}$ & $9.51 \mathrm{a}$ & $39.77 \mathrm{a}$ & $3.95 \mathrm{c}$ & $1563.99 \mathrm{a}$ \\
2nd (121 DAC) & $30.91 \mathrm{a}$ & $9.05 \mathrm{a}$ & $39.96 \mathrm{a}$ & $3.43 \mathrm{bc}$ & $1538.73 \mathrm{a}$ \\
3rd (208 DAC) & $23.03 \mathrm{~b}$ & $6.51 \mathrm{~b}$ & $29.54 \mathrm{~b}$ & $3.57 \mathrm{~b}$ & $1287.42 \mathrm{~b}$ \\
4th (291 DAC) & $14.90 \mathrm{c}$ & $4.13 \mathrm{c}$ & $19.02 \mathrm{c}$ & $3.68 \mathrm{~b}$ & $938.02 \mathrm{c}$ \\
5th (381 DAC) & $16.02 \mathrm{c}$ & $3.63 \mathrm{c}$ & $19.66 \mathrm{c}$ & $4.59 \mathrm{a}$ & $1056.93 \mathrm{c}$ \\
LSD $^{1}$ & 4.02 & 1.27 & 5.25 & 0.31 & 189.43 \\
\hline
\end{tabular}

${ }^{1}$ LSD represents least significant difference.

${ }^{2}$ Means within a column followed by the same letter are not significant at $P \leq 0.05$. 
Table 4. Tukey test of maximum photochemical efficiency of photosystem II $\left(F_{V} / F_{M}\right)$ for sugarcane cv. SP80-3280, obtained under doses of nitrogen $\left(0,50,100,150\right.$, and $\left.200 \mathrm{~kg} \mathrm{ha}^{-1}\right)$ applied via subsurface drip fertigation in five evaluation periods (38, 121, 208, 291, and 381 DAC). Jaú, SP, Brazil, 2009-2010.

\begin{tabular}{lccc}
\hline Treatment doses of $\mathrm{N}\left(\mathrm{kg} \mathrm{ha}^{-1}\right)$ & $\begin{array}{c}\text { Tukey Test }^{2} \\
F_{V} / F_{M}\end{array}$ & Treatment evaluation periods & $\begin{array}{c}\text { Tukey test }^{2} \\
F_{V} / F_{M}\end{array}$ \\
\hline 0 & $0.76 \mathrm{ab}$ & $1 \mathrm{a}(038 \mathrm{DAC})$ & $0.77 \mathrm{ab}$ \\
50 & $0.74 \mathrm{~b}$ & $2^{\mathrm{a}}(121 \mathrm{DAC})$ & $0.78 \mathrm{a}$ \\
100 & $0.77 \mathrm{a}$ & $3^{\mathrm{a}}(208 \mathrm{DAC})$ & $0.78 \mathrm{a}$ \\
150 & $0.77 \mathrm{a}$ & $4^{\mathrm{a}}(291 \mathrm{DAC})$ & $0.75 \mathrm{bc}$ \\
200 & $0.76 \mathrm{ab}$ & $5^{\underline{a}}(381 \mathrm{DAC})$ & $0.74 \mathrm{c}$ \\
LSD $^{1}$ & 0.02 & & 0.02 \\
\hline
\end{tabular}

${ }^{1} \mathrm{LSD}$ represents least significant difference.

${ }^{2}$ Means within a column followed by the same letter are not significant at $\mathrm{P} \leq 0.05$.

the use of light energy by the photosynthetic apparatus (Krause and Weis, 1991; Torres Netto et al., 2005).

Additionally, the photosynthetic capacity of plants depends on the nitrogen supply (Fontes et al., 2008). A considerable fraction of such element is found in leaves, allocated in the proteins involved in the photosynthetic process (Onoda et al., 2004). Also, photosynthesis depends on various nitrogenous compounds, such as enzymes and photosynthetic pigments, for the production of carbon compounds, which comprise the aerial part (Taiz and Zeiger, 2010). The metabolism of nitrogen and carbon are interdependent, given that the energy needed for assimilating nitrogen derives directly or indirectly from photosynthesis, whereas the later depends on nitrogen supply (Fontes et al., 2008).

The late phenological stage of plants and the increase in leaf senescence have interfered negatively in chlorophyll content (Table 3 ) and, as a consequence, contributed for the decrease in $F_{V} / F_{M}$ (Baker and Rosenqvst, 2004) verified at the final evaluation period (Table 4), result that was also observed for the SPAD index (Figure 2).

The IAF presented a significant increase up until 208 DAC due to doses $0,50,100,150$, and $200 \mathrm{~kg}$ $\mathrm{N} \mathrm{ha}^{-1}$, applied via subsurface dripping (Figures $4 \mathrm{~A}, 4 \mathrm{~B}, 4 \mathrm{C}, 4 \mathrm{D}$ and $4 \mathrm{E}$, respectively). This period is characterized by high tillering and emergence of intense amount of leaves. Later, the emission of new leaves and tillers was stabilized, corresponding to the period between 200 and 300 DAC (Ramesh, 2000), when there was a decrease in IAF, associated to the sugarcane maturation phase, that is 360 $\mathrm{DAC}$, in which there is more leaf senescence.

Regarding the nitrogen doses, there was a significant increase in IAF according to the highest concentration of nutrients (Figure 5). However, between 208 and 381 DAC there was a decrease and stabilization of the IAF values, respectively, from $100 \mathrm{~kg} \mathrm{~N} \mathrm{ha}^{-1}$ (Figures 5C and 5E). Wiedenfeld and Enciso (2008) have also recorded an increase in IAF in sugarcane under doses of 0,60, 120, and $180 \mathrm{~kg}$ $\mathrm{N} \mathrm{ha}^{-1}$ applied via dripping.

IAF is a non-dimensional measure, which characterized the plant canopy in an ecosystem (Sandhu et al., 2012) and is related to liquid photosynthesis (accumulation of dry matter mass) obtained by the crops (Wiedenfeld and Enciso, 2008). Such relation is established due to the fact that the IAF is directly associated to the amount of light absorbed and, as a consequence, to the photosynthesis carried out by plants (Scarpari and Beauclair, 2009).

The increase in IAF observed throughout the evaluation periods is probably due to the increase in the number of leaves per stalk and the increase in the leaf area by individual. Such fact may also promote a significant association between crop productivity and the total photosynthetically active surface (Sandhu et al., 2012). Thus, the solar radiation intercepted by leaves and the chemical energy transformations during the photosynthetic process are directly related to determining sugarcane productivity (Teruel et al., 1997). However, the increase in such physiological parameters does not guarantee the same effect on productivity for the entire crop growth period, since after a more advanced development phase a self-shading effect is verified, generating a reduction in photosynthetic rates (Ramesh, 2000). Thus, at the end of the cycle, the reduction of the emission of new leaves, as well as in leaf senescence, 
(A)

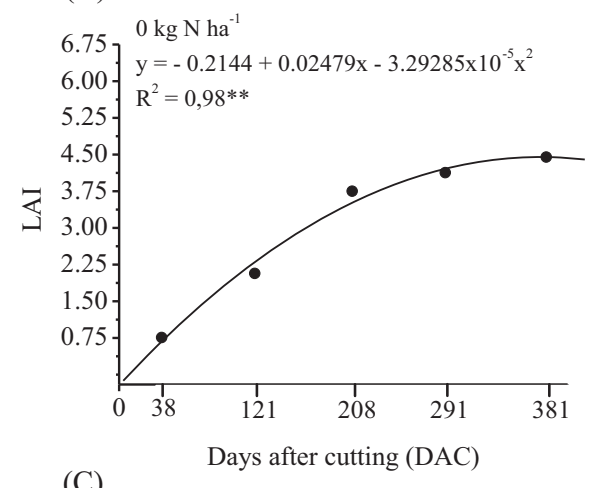

(C)

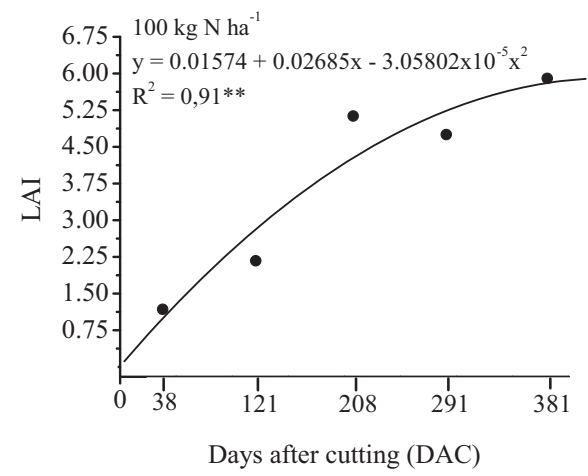

(B)

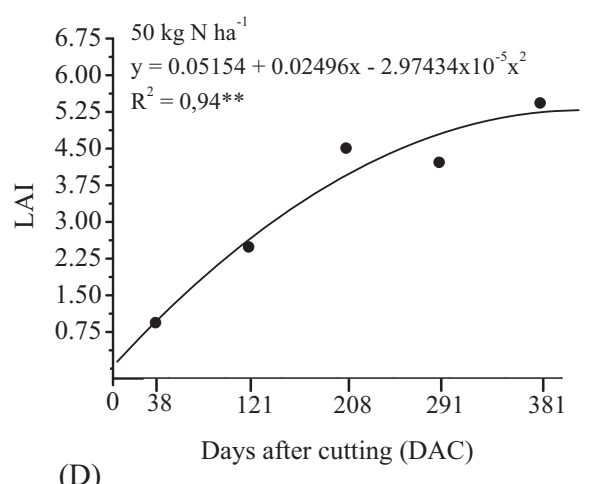

(D)

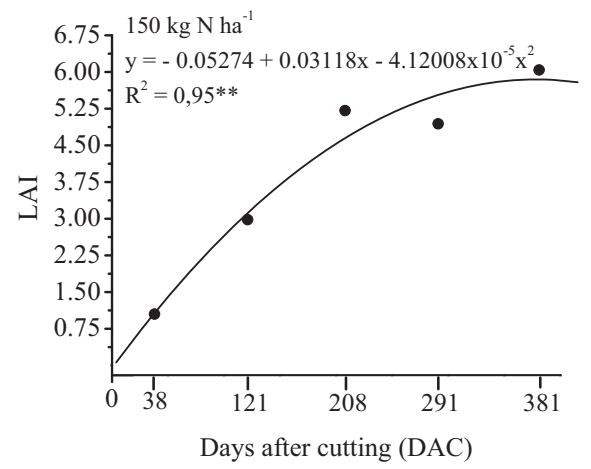

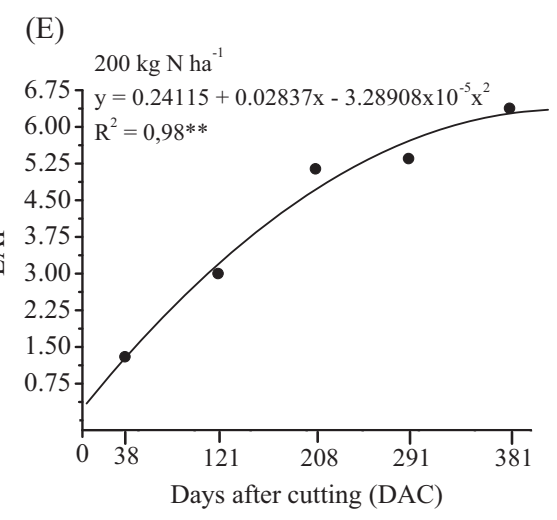

Figure 4. Mean values of leaf area index (LAl) for sugarcane cv. SP80-3280, obtained in five evaluation periods (38, 121, 208, 291, and $381 \mathrm{DAC}$ ) in doses of $0,50,150$, and $200 \mathrm{~kg} \mathrm{~N} \mathrm{ha}^{-1}$ applied via subsurface drip fertigation, represented in graphs $A, B, C, D$, and $E$, respectively. Jaú, SP, Brazil. 2009-2010.

exceed the beneficial effects of nitrogen fertilization on IAF, as already concluded in other studies $(\mathrm{Ng}$ Kee Kwong et al., 1999).

\section{Productivity}

There was a considerable increase in sugarcane stalk productivity (TSH) after the third cut with the increase on nitrogen doses applied via subsurface dripping (Figure 6). The 150 and $200 \mathrm{~kg} \mathrm{~N} \mathrm{ha}{ }^{-1}$ doses have generated 100 and $120 \mathrm{t} \mathrm{ha}^{-1} \mathrm{TSH}$, respectively. Dalri and Cruz (2008) also reported an increase of productivity of stalks for ratoon cane cycle under subsurface drip fertigation. Wiedenfeld and Enciso (2008) obtained 108 and $115 \mathrm{t} \mathrm{ha}^{-1} \mathrm{TSH}$ in second cut sugarcane under 70 and $140 \mathrm{~kg} \mathrm{~N}$ $\mathrm{ha}^{-1}$ doses applied via subsurface dripping, respectively. Such results may indicate that the demand for 


\section{(A)}
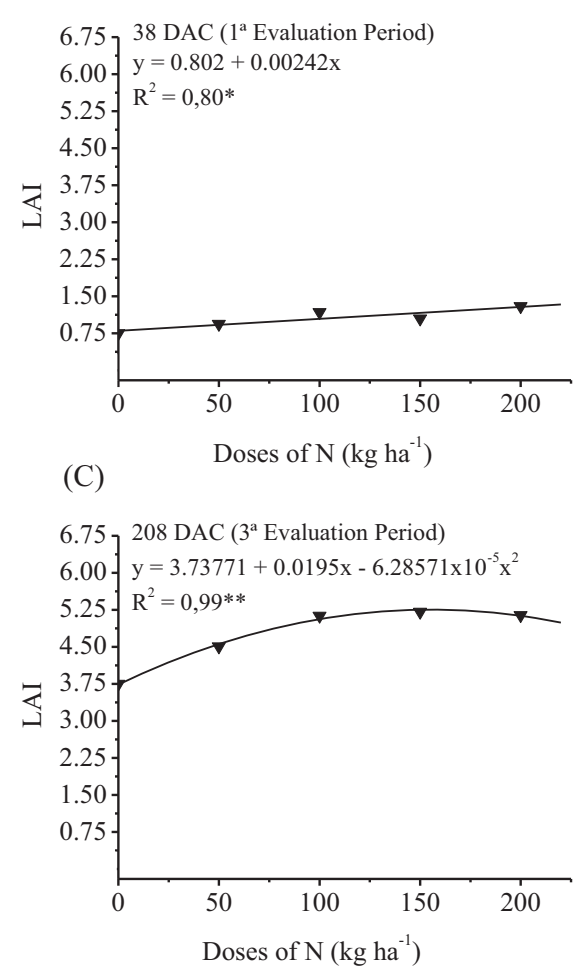

(B)

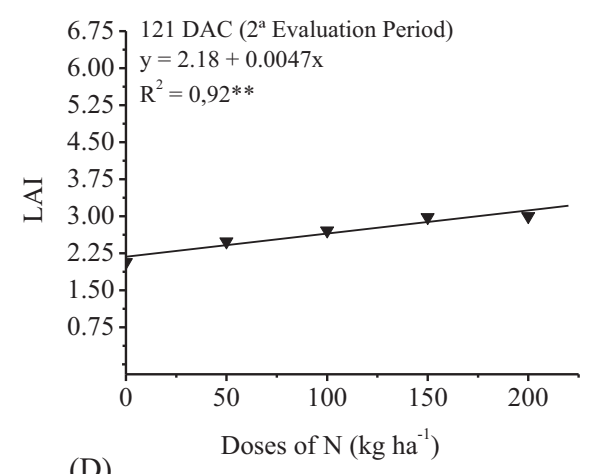

(D)

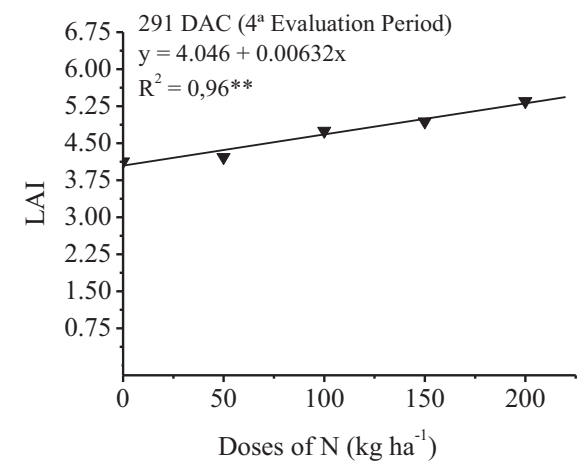

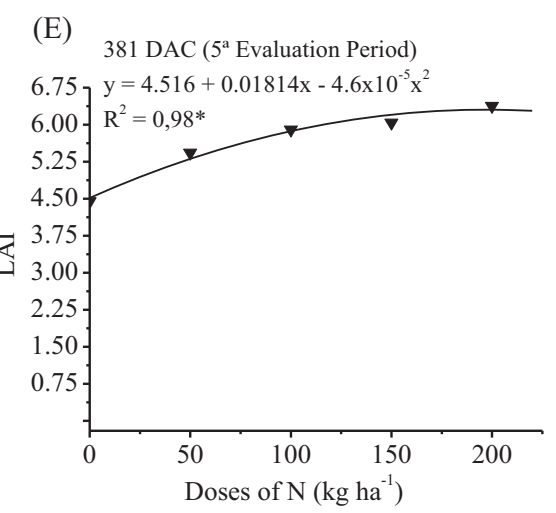

Figure 5. Mean values of leaf area index (LAI) for sugarcane cv. SP80-3280, obtained under doses of nitrogen $(0,50,100,150$, and $200 \mathrm{~kg} \mathrm{~N} \mathrm{ha}^{-1}$ ) applied via subsurface drip fertigation in five evaluation periods (38, 121, 208, 291, and 381 DAC), represented in graphs A, B, C, D, and E, respectively. Jaú, SP, Brazil. 2009-2010.

nitrogen in irrigated sugarcane ratoon can be higher than the currently recommended dose for dry farming management, which varies between 100 and $120 \mathrm{~kg} \mathrm{~N} \mathrm{ha}^{-1}$ for productivities expected to be above $100 \mathrm{t}$ stalks ha ${ }^{-1}$ (Van Raij et al., 1997).

Sugar productivity (TPH) increased from 10 to $18 \mathrm{t} \mathrm{ha}^{-1}$ under the 150 and $200 \mathrm{~kg} \mathrm{~N} \mathrm{ha}^{-1}$ doses (Figure 7). Muchow et al. (1996) also reported an increase in TPH in sugarcane under growing doses of nitrogen. Wiedenfeld (2000) obtained a $10 \mathrm{t} \mathrm{ha}^{-1} \mathrm{TPH}$ of second ratoon sugarcane fertigated with $140 \mathrm{~kg} \mathrm{~N} \mathrm{ha}^{-1}$.

The adequate management of dripping irrigation can increase the water and nutrient use efficiency, such as nitrogen, leading to an increase in stalk and sugar productivity (Ng Kee Kwong et al., 1999).

The response potential to nitrogen fertilization in ratoon cane has proven to be superior, more frequent, and requiring higher doses of nitrogen compared to plant cane. The nitrogen doses currently recommended underestimates the potential of economic response to nitrogen in sugarcane, whose 


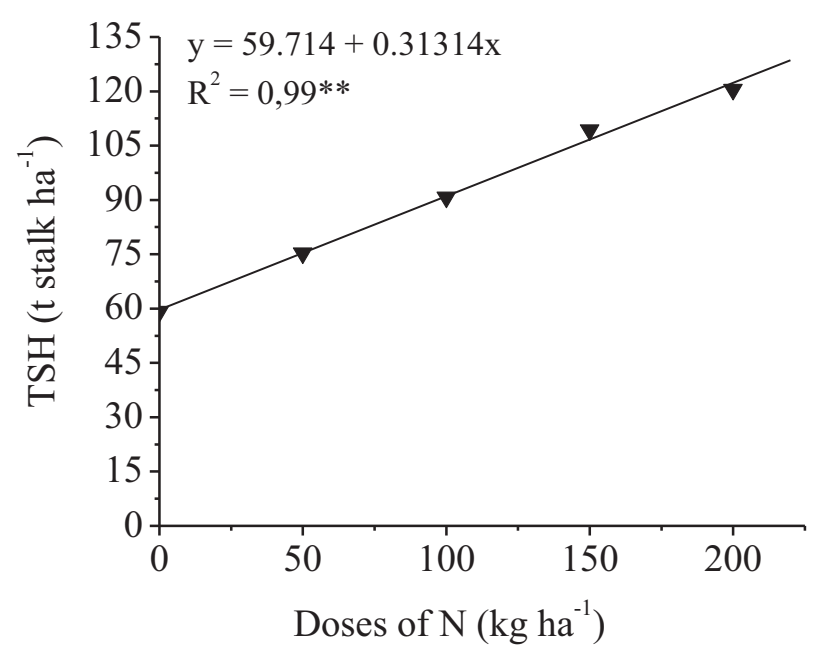

Figure 6. Stalk productivity (TSH), t stalk ha ${ }^{-1}$, mean values for sugarcane cv. SP80-3280, obtained under doses of nitrogen $(0,50,100$, 150, and $200 \mathrm{~kg} \mathrm{~N} \mathrm{ha}^{-1}$ ) applied via drip fertigation subsurface, to 381 DAC. Jaú, SP, Brazil, 2009-2010.

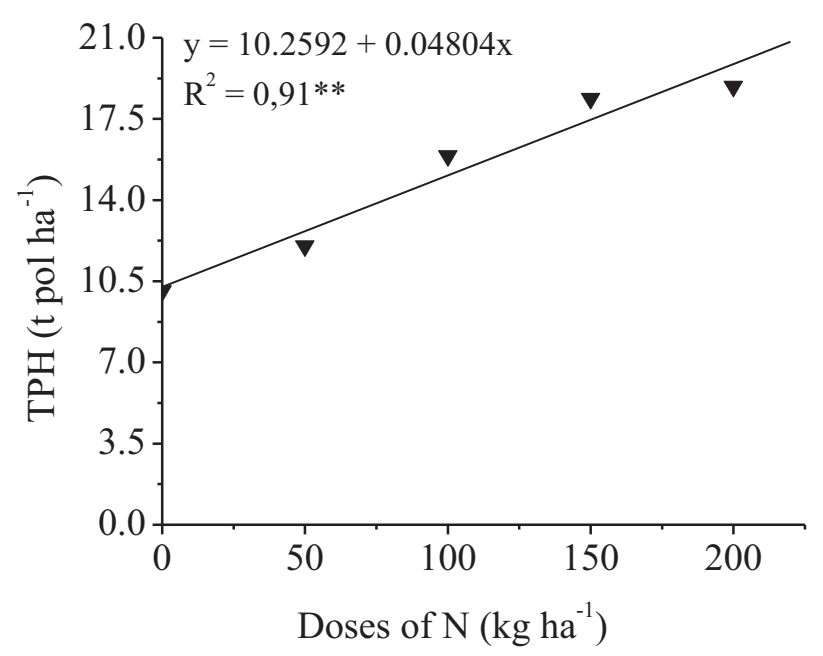

Figure 7. Sugar productivity (TPH), t pol ha ${ }^{-1}$, mean values for sugarcane cv. SP80-3280, obtained under doses of nitrogen $(0,50,100$, 150 , and $200 \mathrm{~kg} \mathrm{~N} \mathrm{ha}^{-1}$ ) applied via drip fertigation subsurface, to 381 DAC. Jaú, SP, Brazil, 2009-2010.

genetic material is more productive, grown in environments of higher production potential and with high amounts of waste (straw) with high ratio C:N (Vitti et al., 2010), as verified in the present study. Additionally, the application of $\mathrm{N}$-fertilizers in ratoons is necessary and presents great variations, depending on management and type of soil (Gava et al., 2001). Thereby, fertigation with nitrogen has become relevant and compensatory for obtaining gains in productivity.

\section{Conclusions}

The physiological attributes SPAD index, chlorophyll and carotenoids contents, maximum photochemical efficiency of photosystem II $\left(F_{V} / F_{M}\right)$, and leaf area index increase with the application of increasing doses of nitrogen via subsurface drip fertigation, but the best results are obtained in doses of 100 and $150 \mathrm{~kg} \mathrm{~N} \mathrm{ha}^{-1}$ and in the period of great plant growth.

It was also concluded that the stalk and sugar productivity increases considerably with the increase of nitrogen doses applied to sugarcane via subsurface drip fertigation. 


\section{References}

Alfonsi, R. R., M. J. Pedro Junior, O. Brunini, and V. Barbieri. 1987. Climatic conditions for sugarcane. In: Sugarcane: Cultivation and Use, ed. S.B. Paranhos, pp. 42-55. Campinas, Brazil: Fundação Cargill (in Portuguese).

Baker, N., and E. Rosenqvist. 2004. Applications of chlorophyll fluorescence can improve crop production strategies: An examination of future possibilities. Journal of Experimental Botany 55: 1607-1621.

Bartels, D., and R. Sunkar. 2005. Drought and salt tolerance in plants. Critical Reviews in Plant Sciences 24: 23-58.

Dalri, A. B., and R. L. Cruz. 2008. Productivity of sugarcane fertigation with NK by subsurface drip. Engenharia Agricola 28: 516-524 (in Portuguese).

Dalri, A. B., R. L. Cruz, C. J. B. Garcia, and L. H. Duenhas. 2008. Subsurface drip irrigation on sugarcane yield and quality. Irriga 13: 1-11 (in Portuguese).

Fontes, R. V., M. P. Santos, A. R. Falqueto, and D. M. Silva. 2008. Nitrate reductase activity and chlorophyll $a$ fluorescence in papaya. Revista Brasileira de Fruticultura 30: 251-254 (in Portuguese).

Force, L., C. Critchley, and J. J. S. Van Rensen. 2003. New fluorescence parameters for monitoring photosynthesis in plants. Photosynthesis Research 78: 17-33.

Gava, G. J. C., P. C O. Trivelin, M. W. Oliveira, and C. P. Penatti. 2001. Growth and accumulation of nitrogen by sugarcane cultivated in soil covered with cane trash. Pesquisa Agropecuária Brasileira 36: 1347-1354 (in Portuguese).

Glaz, B., S. T. Reed, and J. P. Albano. 2008. Sugarcane response to nitrogen fertilization on a histosol with shallow water table and periodic flooding. Journal of Agronomy and Crop Science 194: 369-379.

Howell, T. A., and S. R. Evett. 2004. The Penman-Monteith Method. Washington, DC: USDA-Agricultural Research Service, Conservation \& Production Research Laboratory.

Kawamitsu, Y., B. J. Nelson, and Y. Tamaki. 1999. Effects of nitrogen supply on growth characteristics and leaf photosynthesis in sugarcane. Science Bulletin of the Faculty of Agriculture 46: 1-14.

Kopsell, D. A., D. E. Kopsell, and J. Curran-Celentano. 2007. Carotenoid pigments in kale are influenced by nitrogen concentration and form. Journal of the Science of Food and Agriculture 87: 900-907.

Krause, G. H., and E. Weis. 1991. Chlorophyll fluorescence and photosynthesis: The basics. Annual Review of Plant Physiology and Plant Molecular Biology 42: 313-349.

Lefsrud, M. G., D. A. Kopsell, and D. E. Kopsell. 2007. Nitrogen levels influence biomass, elemental accumulations, and pigment concentrations in spinach. Journal of Plant Nutrition 30: 171-185.

Lichtenthaler, H. K. 1987. Chlorophylls and carotenoids: Pigments of photosynthetic biomembranes. Methods in Enzymology 148: 350-382.

Meschede, D. K., E. D. Velini, C. A. Carbonari, and J. R. M. Silva. 2011. Physiological alteration in sugarcane influenced by glyphosate and sulfumeturon-methyl application. Planta Daninha 29: 413-419 (in Portuguese).

Muchow, R. C., M. J. Robertson, A. W. Wood, and B. A. Keating. 1996. Effect of nitrogen on the time-course of sucrose accumulation in sugarcane. Field Crops Research 47: 143-153.

Ng Kee Kwong, K. F., J. P. Paul, and J. Deville. 1999. Drip-fertigation - a means for reducing fertilizer nitrogen to sugarcane. Experimental Agriculture 35: 31-37.

Oliveira, R. A., E. Daros, J. L. C. Zambon, H. Weber, O. T. Ido, K. C. Zuffellato-Ribas, H. S. Koehler, and D. K. T. Silva. 2005. Growth development of three varieties of sugarcane, in cane-plant, in the Parana state: Growth indexs. Scientia Agraria 6: 85-89 (in Portuguese).

Onoda, Y., K. Hikosaka, and T. Hirose. 2004. Allocation of nitrogen to cell walls decreases photosynthetic nitrogen-use efficiency. Functional Ecology 18: 419-425.

Pedó, T., J. Borella, T. Z. Aumonde, L. Amarante, D. M. Moraes, T. B. G. A. Morselli, and C. R. Mauch. 2012. Growth of cabbage seedlings and content of photosynthetic pigments under the influence of nitrogen sources. Tecnologia e Ciência Agropecuária 6: 23-27 (in Portuguese).

Phogat, V., M. A. Skewes, J. W. Cox, J. Alam, G. Grigson, and J. Simunek. 2013. Evaluation of water movement and nitrate dynamics in a lysimeter planted with an orange tree. Agricultural Water Management 127: 74-84.

Politycka, B., and A. Golcz. 2004. Content of chloroplast pigments and anthocyanins in the leaves of Ocimum basilicum L. depending on nitrogen doses. Folia Horticulture 16: 23-29.

Ramesh, P. 2000. Effect of different levels of drought during the formative phase on growth parameters and its relationship with dry matter accumulation in sugarcane. Journal of Agronomy and Crop Science 185: 83-89.

Roberts, T. L. 2008. Improving nutrients use efficiency. Turkish Journal of Agriculture and Forestry 32: 177-182.

Sandhu, H. S., R. A. Gilbert, J. M. Mccray, R. Perdomo, B. Eiland, G. Powell, and G. Montes. 2012. Relationships among leaf area index, visual growth ratings, and sugarcane yield. Journal American Society of Sugar Cane Technologists 32: 1-14.

Santos, C. L. V., A. Campos, H. Azevedo, and G. Caldeira. 2001. In situ and in vitro senescence induced by KCl stress: Nutritional imbalance, lipid peroxidation and antioxidant metabolism. Journal of Experimental Botany 52: 351-360.

Scarpari, M. S., and E. G. F. Beauclair. 2009. Physiological model to estimate the maturity of sugarcane. Scientia Agricola 66: 622-628.

Shekinah, D. E., B. Sundara, and P. Rakkiyappan. 2012. Relative significance of N nutrition on yield, quality and ethanol in sugarcane (Saccharum species hybrid) plant: Ratoon system. Sugar Tech 14: 134-137.

Silva, M. A., J. L. Jifon, J. A G. Silva, and V. Sharma. 2007. Use of physiological parameters as fast tools to screen for drought tolerance in sugarcane. Brazilian Journal of Plant Physiology 19: 193-201. 
Silva, M. A., J. A. G. Silva, J. Enciso, V. Sharma, and J. Jifon. 2008. Yield components as indicators of drought tolerance of sugarcane. Scientia Agricola 65: 620-627.

Silveira, P. M., A. J. B. P. Braz, and A. D. Didonet. 2003. Chlorophyll meter to evaluate the necessity of nitrogen in dry beans. Pesquisa Agropecuária Brasileira 38: 1083-1087 (in Portuguese).

Taiz, L., and E. Zeiger. 2010. Plant Physiology. Sunderland, MA: Sinauer Associates.

Teruel, D. A., V. Barbieri, and L. A. Ferraro. 1997. Sugarcane leaf area index modeling under different soil water conditions. Scientia Agrícola 54: 39-44.

Torres Netto, A., E. Campostrini, J. G. O. Oliveira, and R. E. Bressan-Smith. 2005. Photosynthetic pigments, nitrogen, chlorophyll $a$ fluorescence and SPAD-502 readings in coffee leaves. Scientia Horticulturae 104: 199-209.

Vale, D. W., R. M. Prado, H. Cantarella, I. M. Fonseca, C. C. AvalhãesM. A. R. Correia, and M. P. Barbosa. 2013. Ammonium and nitrate in soil and ratoon sugarcane grown in function of nitrogen on oxisol. Journal of Plant Nutrition 36: 201-213.

Van Raij, B., H. Cantarella, J. A. Quaggio, and A. M. C. Furlani. 1997. Fertilizing and Liming Recommendations for the State of São Paulo. (Boletim Técnico, 100). 2nd ed. Campinas, Brazil: Instituto Agronômico/Fundação IAC (in Portuguese).

Vieira, M. X., P. C. O. Trivelin, H. C. J. Franco, R. Otto, and C. E. Faroni. 2010. Ammonium chloride as nitrogen source in sugarcane harvested without burning. Revista Brasileira de Ciência do Solo 34: 1165-1174.

Vitti, A. C., H. Cantarella, P. C. O. Trivelin, and R. Rossetto. 2010. Nitrogen. In: Sugarcane, eds. L. L. Dinardo-Miranda, A. C. M. Vasconcelos, and M. G. A. Landell, pp. 239-270. Campinas, Brazil: Instituto Agronômico (in Portuguese).

Wiedenfeld, R. P. 2000. Water stress during different sugarcane growth periods on yield and response to $\mathrm{N}$ fertilization. Agricultural Water Management 43: 173-182.

Wiedenfeld, B., and J. Enciso. 2008. Sugarcane responses to irrigation and nitrogen in semiarid south Texas. Agronomy Journal 100: 665-671. 